\title{
COVID-19: IgG seroconversion under intensive glucocorticoid treatment in a high-risk patient with minimal change disease
}

\author{
Michael Eder · Robert StrassI · Johannes Kläger · Christof Aigner · Florian Thalhammer · Željko Kikić
}

Received: 8 September 2020 / Accepted: 12 November 2020 / Published online: 8 December 2020

(C) The Author(s) 2020

\begin{abstract}
Summary In this case report we present a rare case of a patient with multiple risk factors for severe coronavirus disease (COVID 19) in whom intensive glucocorticoid treatment due to incipient nephrotic syndrome coincided with SARS-CoV-2 infection. Despite this high baseline risk profile and the use of glucocorticoids the patient developed only mild disease including IgG SARS-CoV-2 seroconversion.
\end{abstract}

Keywords Coronavirus · Hyperinflammatory syndrome · Kidney disease · Glomerulonephritis · Immunosuppression

The role of immunosuppressive strategies in patients with coronavirus disease (COVID-19) is controversially discussed in the literature $[1,2]$. The World Health Organization (WHO) argues against the rou-

The findings presented in this article have not been published previously in whole or part, except in abstract format.

M. Eder, M.D. · C. Aigner, M.D. ·

Assoc. Prof. PD Dr. Ž. Kikić, M.D. $(\varangle)$

Department of Internal Medicine III, Division of Nephrology and Dialysis, Medical University of Vienna, Vienna, Austria zeljko.kikic@meduniwien.ac.at

\section{R. Strassl, M.D.}

Division of Clinical Virology, Department of Laboratory Medicine, Medical University of Vienna, Vienna, Austria

\section{J. Kläger, M.D.}

Department of Pathology, Medical University of Vienna, Vienna, Austria

\section{F. Thalhammer, M.D.}

Department of Internal Medicine I, Division of Infectious Diseases and Tropical Medicine, Medical University of Vienna, Vienna, Austria tine use of glucocorticoids due to prolonged viral shedding and reduced anti-viral type 1 interferon immune responses [3]. As suggested by Mehta et al. these concerns are countered by increasing evidence of COVID-19 subpopulations in which development of severe ARDS and multiorgan failure may be driven by virally induced secondary hyperinflammatory syndrome (SHS) and cytokine storm [1, 4]. Anecdotal reports in subjects without renal disease have suggested successful reversion of critical cases by nonselective (glucocorticoids, Intravenous immunoglobulin) or selective immunosuppression, i.e. interleukin 6 (IL-6) antagonism, mostly used as bail-out procedures. Prevention of severe COVID-19 and/or SHS at earlier disease stages through immunosuppression, however, may also be beneficial. So far, the evidence for prophylactic glucocorticoids treatment in nonsevere cases is limited by various uncertainties regarding optimal case selection, timing and dose of immunosuppression. Moreover, knowledge about immunocompromised patients with renal disease is derived mainly from case reports of renal transplant patients with varying clinical course but a not unsubstantial number of patients needed treatment at ICU units [5]. In this report we discuss a case of a patient with multiple risk factors for severe COVID19 (obesity, renal disease, hypertension) in whom intensive glucocorticoid treatment due to incipient nephrotic syndrome coincided with SARS-CoV-2 infection. Despite this high baseline risk profile and the use of glucocorticoids the patient developed only mild disease including IgG SARS-CoV-2 seroconversion.

A 32-year-old male patient presented at our outpatient clinic with progressive fatigue, weight gain and edema. Physical examination showed an obese patient $(163 \mathrm{~kg})$ with lower extremity edema and mild hypertension $(140 / 90 \mathrm{~mm} \mathrm{Hg})$. Laboratory findings (Table 1) confirmed a severe nephrotic syndrome (pro- 
Table 1 Laboratory findings of the described case, obtained at the nephrology outpatient clinic

\begin{tabular}{|c|c|c|c|}
\hline & $\begin{array}{l}13 \text { February } \\
2020\end{array}$ & $\begin{array}{l}11 \text { March } \\
2020\end{array}$ & $\begin{array}{l}15 \text { April } \\
2020\end{array}$ \\
\hline Hemoglobin, g/dl & 13.9 & 14.5 & 16.4 \\
\hline Leukocytes, G/L & 10.79 & 9.05 & 18.07 \\
\hline Thrombocytes, G/L & 380 & 337 & 298 \\
\hline Serum creatinine, mg/dl & 0.68 & 0.71 & 0.81 \\
\hline Albumin, $g / L$ & 17.0 & 16.2 & 47.1 \\
\hline LDH, U/L & 277 & 227 & 243 \\
\hline $\mathrm{CRP}, \mathrm{mg} / \mathrm{dl}$ & 0.26 & 0.29 & 0.04 \\
\hline $\begin{array}{l}\mathrm{P} / \mathrm{C} \text { ratio in spot urine, } \\
\mathrm{mg} / \mathrm{g}\end{array}$ & 6384 & 9932 & $<0.05$ \\
\hline $\begin{array}{l}\mathrm{A} / \mathrm{C} \text { ratio in spot urine, } \\
\mathrm{mg} / \mathrm{g}\end{array}$ & $4391^{a}$ & $6510^{b}$ & $<0.05$ \\
\hline \multicolumn{4}{|c|}{$\begin{array}{l}A C \text { albumin/creatinine ratio, } L D H \text { lactate dehydrogenase, } P / C \text { protein/ } \\
\text { creatinine, } C R P C \text {-reactive protein } \\
{ }^{a} \text { measured on } 17 \text { February } \\
{ }^{\circ} \text { measured on } 6 \text { March }\end{array}$} \\
\hline
\end{tabular}

tein/creatinine ratio $6348 \mathrm{mg} / \mathrm{g}$, hypoalbuminemia of $17 \mathrm{~g} / \mathrm{L}$ ), hypogammaglobulinemia (IgG $444 \mathrm{mg} / \mathrm{dL}$ ) and no autoantibodies. The remaining laboratory findings (Table 1) showed normal creatinine and electrolytes or blood counts. Sonography revealed normal renal morphology. Renal biopsy showed no relevant pathologies in light microscopy and immunohistochemistry. Electron microscope findings confirmed the renal diagnosis of minimal change disease with podocyte flattening of $90 \%$. After confirmation of the diagnosis high-dose glucocorticoid treatment with $75 \mathrm{mg}$ aprednislone/day was established on 11 March due to progressive proteinuria despite use of ACE inhibitors (ramipril $1.25 \mathrm{mg}$ q.d.). Furosemide $40 \mathrm{mg}$ b.i.d was continued until remission. The patient developed afebrile mild respiratory infection symptoms (dry cough) 2 days later, diarrhea for 4 days and was tested positive for SARSCoV-2 (PCR) on 21 March. Patient history revealed category I contact on 10 March to an infected coworker. No further symptoms occurred and the dose of glucocorticoids remained unchanged in the course of the quarantine of 14 days. A clinical and laboratory follow-up on 15 April showed complete remission of the nephrotic syndrome (Table 1) and virological clearance (negative nasopharyngeal and stool PCR; Roche Diagnostics, Mannheim, Germany) including IgG and IgA seroconversion (Euroimmun, Lübeck, Germany). SARS-CoV-2 IgG and IgA was considered positive according to the manufacturer's manual with an antibody ratio $>1.1$.

This case delivers new insight into this patient group otherwise classified as high-risk and also illus- trates that intensive glucocorticoid treatment did not negatively influence the course of disease in selected COVID-19 cases with native kidney disease.

Funding Open access funding provided by Medical University of Vienna.

\section{Compliance with ethical guidelines}

Conflict of interest M. Eder, R. Strassl, J. Kläger, C. Aigner, F. Thalhammer, and Ž. Kikić declare that they have no competing interests.

Ethical standards The patient participating in this case report provided informed consent prior to publication.

Open Access This article is licensed under a Creative Commons Attribution 4.0 International License, which permits use, sharing, adaptation, distribution and reproduction in any medium or format, as long as you give appropriate credit to the original author(s) and the source, provide a link to the Creative Commons licence, and indicate if changes were made. The images or other third party material in this article are included in the article's Creative Commons licence, unless indicated otherwise in a credit line to the material. If material is not included in the article's Creative Commons licence and your intended use is not permitted by statutory regulation or exceeds the permitted use, you will need to obtain permission directly from the copyright holder. To view a copy of this licence, visit http://creativecommons.org/licenses/by/4.0/.

\section{References}

1. Mehta P, McAuley DF, Brown M, Sanchez E, Tatersall RS, Manson JJ, et al. COVID-19: consider cytokine storm syndromes and immunosuppression. Lancet. 2020;395(10229):1033-4. https://doi.org/10.1016/S01406736(20)30628-0.

2. Ritchie AI, Singanayagam A. Immunosuppression for hyperinflammation in COVID-19: a double-edged sword? Lancet. 2020;395(10230):1111. https://doi.org/10.1016/ S0140-6736(20)30691-7.

3. Thomas BJ, Porritt RA, Hertzog PJ, Bardin PG, Tate MD. Glucocorticosteroids enhance replication of respiratory viruses: effect of adjuvant interferon. Sci Rep. 2014;4:7176. https://doi.org/10.1038/srep07176.

4. Ruan Q, Yang K, Wang W, Jiang L, Song J. Clinical predictors of mortality due to COVID-19 based on an analysis of data of 150 patients from Wuhan, China. Intensive Care Med. 2020; https://doi.org/10.1007/s00134-020-06028-z.

5. Guillen E, Pineiro GJ, Revuelta I, Rodriguez D, Bodro M, Moreno A, et al. Case report of COVID-19 in a kidney transplant recipient: Does immunosuppression alter the clinical presentation? Am J Transplant. 2020;20(7):1875-1878. https://doi.org/10.1111/ajt.15874.

Publisher's Note Springer Nature remains neutral with regard to jurisdictional claims in published maps and institutional affiliations. 